\title{
M.O.Chaban*, Y.S.Dzyazko, O.V.Bystryk \\ MATERIALS BASED ON TITANIUM AND MANGANESE OXIDES FOR SELECTIVE RECOVERY OF LITHIUM FROM WATER SOURCES
}

\author{
V.I.Vernadsky Institute of General and Inorganic Chemistry of the National Academy of Sciences \\ of Ukraine, 32/34 Academic Palladin Avenue, Kyiv, 03142, Ukraine \\ *e-mail: mary.chaban@gmail.com
}

\begin{abstract}
Due to the ever-increasing production of electronic portable devices, including gadgets, lithium recovery is used to produce lithium-ion batteries. Lithium is electrochemically active, has the highest value of oxidation-reducing potential and the highest specific heat capacity among solid materials, making it a key element in the modern revolution of electric vehicles. The crust contains about $0.007 \%$ lithium, which is not in its pure form, but its insignificant concentrations are found in virtually all volcanic rocks and in the waters of mineral springs, sea water, and oceans. There are more than 20 minerals that contain lithium, but only few of them have content that is sufficient for commercial interest. A promising area is the processing of brines that are formed after desalination of seawater and mine waters. It is environmentally friendly and cost-effective. Since the concentration of lithium in such resources is low, sorption methods are advantageous compared to other. In this article materials that are widely studied in order to produce lithium-selective adsorbents are described. Most amphoteric oxides and hydroxides are amphoteric ion exchanges having both cation exchange and anion exchange properties. Such materials are of scientific interest in connection with the study of fission fragments behavior, release of radioactive isotopes, decontamination of sewage and concentration of microquantities of elements. The synthesis of such ion exchangers as amphoteric oxides and hydroxides is fairly simple and their cost per unit of capacity in most cases is much lower than the cost of organic resins. The combination of the material formed on the basis of hydrated titanium dioxide with known lithium manganese spinels allows to obtain a strong ion-exchange material for the selective extraction of lithium ions.
\end{abstract}

$\mathrm{K}$ e y w o r d s: titanium dioxide, manganese oxide, lithium, ion-exchange material.

INTRODUCTION. The number of high-tech and alternative energy products that are being developed and used is steadily increasing, particularly in the fields of information, communication technologies, energy and mobility. Such growth contributes to the demand for metals that previously had a limited range of applications.

Most of these technological metals are geochemically rare; their average mass concentration in the earth's crust is less than $0.01 \%$ [1]. Because of their importance in modern technology, scientists have begun to search for sources for the extraction of such metals.

Some of the studies conducted have determi- ned that the extraction of technological metals is a multifactorial task, which, among other things, depends on the environment. For example, since mine development affects the quality of air, water and soil, states often start protecting the environment by inhibiting the extraction of metals. Technological innovation helps meet growing needs, but there is a point of view that negative effects can only be delayed [2].

In order to determine how significant these impacts are from a social point of view, it is necessary to consider in which products these metals are used and which processes can provide. Significant resource costs can be justified if the 
use of metal can replace the less efficient technology, with the use of which the benefits to the environment will dominate the cost of extraction.

\section{Existing needs in lithium and perspectives}

Lithium is electrochemically active, has the highest value of oxidation-reducing potential and the highest specific heat capacity among solid materials, making it a key element in the modern revolution of electric vehicles.

Energy conservation is a key factor in the use of electric vehicles. Lithium-ion batteries are perceived as traction batteries in demand for electromobility. The long-term dominance of lithium battery chemistry is anticipated, which makes lithium one of the most important elements for the development of electric vehicles in both short and long-term periods.

Lithium is only a small part of a lithium battery: 39 grams of lithium carbonate per kilogram of the final battery, equal to $12 \mathrm{~kg}$ of lithium carbonate per vehicle with $300 \mathrm{~kg}$ of battery. The amount of lithium needed for the production of batteries increases by more than $20 \%$ each year and is projected to continue in the coming years [3]. However, the lithium market is not limited to the production of batteries - batteries are the largest category in lithium consumption (21\% of the market in 2009), since they are used in electronics, but other uses of lithium are ceramic and glass industry $(30 \%)$, lubricants $(10 \%)$, air treatment $(5 \%)$, metallurgy $(5 \%)$ and primary production of aluminum (3\%) [4].

Today, $35 \%$ of the world's production of lithium is used for lithium-ion batteries, and the growth is projected to rise to $66 \%$ by 2025 . In recent years, the volume of lithium production is almost unchanged, and in terms of spent materials, less than one percent of lithium is recycled for reuse [5]. The demand for lithium is increasing annually by $5-7 \%$ and will continue to grow at the same pace for another decade. This does not take into account the possible increase in the production of hybrid and electric vehicles [6].

\section{Production of lithium}

The crust contains about $0.007 \%$ lithium, which is not in its pure form, but its insignificant concentrations are found in virtually all volcanic rocks and in the waters of mineral springs, sea water, and oceans. There are more than 20 minerals that contain lithium, but only four of them (lepidolite, spodumene, petalite and ambligonite) have content that is sufficient for commercial interest. The most important ore for the lithium industry is spodumene $\left(\mathrm{LiAlSi}_{2} \mathrm{O}_{6}\right)$ [7]. Most lithium is extracted from brines or sea water in the form of concentrated carbonate during warm time of the year. Brines from the earth's crust, called continental/subterranean brines, are the main source of lithium carbonate production.

Active lithium extractions from natural brines are known in Chile, Argentina, the USA and China. All processes are based on solar evaporation for the concentration of brine, sometimes in combination with precipitators or sorbents based on aluminum oxide for selective recovery of lithium [8]. The largest producer of lithium materials SQM works with brines from Salar de Atacama in Chile, with an initial concentration of lithium of $0.15 \%$. The use of "free" solar energy for evaporation is a very important aspect in reducing the energy needs of the enterprise. The productivity of the production depends on the topographical conditions (average temperature, wind, humidity) and the composition of the brine (the initial content of lithium and other elements, in particular, magnesium, which forms hygroscopic salts and keeps a portion of lithium-containing brine) [8].

The development of ore deposits is active in Australia, Brazil, Canada, China, Portugal, and Zimbabwe. Lithium is found in many minerals, but only spodumene or petalite ores are commercially interesting. Concentrates of ore containing lithium oxide, are used mainly in the glass and ceramic industry and are not converted to lithium carbonate, since obtaining carbonate from brines is much cheaper [9].

The problem of producing lithium from seawater has been considered since 1970, when it was assumed that thermonuclear installations would greatly increase the demand for lithium. Due to the positive prospects for lithium-ion batteries, the problem has become relevant again. Sea water is 
an attractive source of lithium, as the total lithium content in it is about $2.4 \cdot 10^{11}$ tons. However, the average concentration of lithium is $0.173 \mathrm{mg} / \mathrm{l}$, which is approximately 10 thousand times less than that in brines [10].

It was proposed to combine solar evaporation, ion exchange and dilution of lithium chloride. Recent studies focus on ion-exchange methods, in particular, on adsorbents based on manganese oxide because of its high selectivity to lithium ions. However, for today the existence of real factories that would use these technologies is unknown.

With an efficiency of $20 \%$ and a concentration of $0.173 \mathrm{mg} / \mathrm{l}$ to produce $1 \mathrm{~kg}$ of lithium carbonate, $5430 \mathrm{~m}^{3}$ of seawater must be processed. In order to meet current needs (68500 tons in 2010) only with sea water, it is necessary to process $3.7 \cdot 10^{11} \mathrm{~m}^{3}$ of water per year.

Lithium from brines is estimated to cover only $0.49-1.37 \%$ of the needs for lithium batteries, while producing lithium from seawater can cover $32-82 \%$ of the needs [8].

From the calculations made it can be concluded that the costs of lithium production will not be overcome by the advantages of electric motors for the environment, unless sea water is used as a source of lithium.

\section{Hydrated titanium dioxide}

Most amphoteric oxides and hydroxides are amphoteric ion exchanges having both cation exchange and anion exchange properties. Such materials are of scientific interest in connection with the study of fission fragments behavior, release of radioactive isotopes, decontamination of sewage from radiochemical industries, studies in the field of radiochromatography and concentration of microquantities of radioactive elements.

Inorganic ion exchangers have several advantages over synthetic resins, since in most cases the latter are destroyed in solutions at temperatures above $150{ }^{\circ} \mathrm{C}$, as well as unstable against aggressive media and radiation, in contrast to inorganic ion exchangers.

The synthesis of such ion exchangers as amphoteric oxides and hydroxides is fairly simple and their cost per unit of capacity in most cases is much lower than the cost of organic resins [11].

When using inorganic ion exchangers for the purification and decontamination of industrial solutions and sewage, it is often not necessary to regenerate ion exchanger, its one-time use is economically justified. Such inorganic ion exchangers, which have zirconium and uranium hydroxides (as well as zirconium phosphate), are characterized by high selectivity and allow clear separation of elements of the same group of periodic system.

In addition to ion-exchange sorption, amphoteric oxides and hydroxides also have the ability to chemical and molecular sorption.

The main disadvantage of such materials is their low sorption capacity compared to synthetic resins. Moreover, amphoteric oxides and hydroxides are dissolved in concentrated solutions of acids and alkalies, which makes impossible to use them in processes with significant change in the concentration of hydrogen ions. However, if a ion exchanger has polymer mesh structure, it is practically stable in any range of $\mathrm{pH}$.

By rational use of the anion and cation exchange properties of hydroxides and oxides, specific amount of impurities can be introduced to the surface, which will have a great influence on the regulation of sorption properties.

It is known that the properties of solids are determined not only by chemical composition, but also by the peculiarities of their structure, therefore, new solid phase materials can, in principle, be created both by the use of new chemical compositions and by the development of new production processes that allow alteration of structural properties dependent on defects in electron and crystalline structure [12].

In the study of the properties of hydrated titanium dioxide, a significant contribution of water to it was found. When investigating such substances for the purpose of their practical use, one of the key issues is the determination of oxygen-water groups, as well as their quantitative ratios and interactions with the ions.

Structure of hydrated titanium dioxide. When systematically studying the ion exchange sorption of cations of mono- and bivalent metals with dif- 
ferent dispersed modifications of titanium (rutile, anatase, amorphous) it was shown that for hydrated titanium dioxide three types of sorption centers with different acidity are usual $\left(\mathrm{p} K_{1}=6-\right.$ $\left.8, \mathrm{p} K_{2}=9.8-10.2, \mathrm{p} K_{3}=11-12\right)$, which are successively filled with sorbed ions when the acidity of the solution decreases. The absence of the first type of sorption centers in rutile determines its significant difference from other modifications of hydrated titanium dioxide. The selectivity of sorption, which is seen mainly in the first stage of exchange, is expressed in the overwhelming sorption of both small $\left(\mathrm{Li}^{+}\right)$and large $\left(\mathrm{K}^{+}\right)$ and similar is size $\left(\mathrm{Ba}^{2+}\right)$ cations. At the same time, ions of medium size $\left(\mathrm{Na}^{+}, \mathrm{Ca}^{2+}, \mathrm{Sr}^{2+}\right)$ are practically not adsorbed. The sorption of selectively absorbed cations is activated - increasing with increasing temperature.

These results can be explained by the following. First, the surface of titanium dioxide is formed by valence-unsaturated oxygen atoms. Given that the coordination number of oxygen in the crystalline modifications of this oxide is equal to three, according to Poling's rule, the uncompensated charge of these atoms, depending on the coordination degree from the substrate by the titanium atoms, may vary and equal to the number of fractions of three $-2 / 3$ and $-4 / 3$ (for cases of coordination from the matrix with two and one titanium atoms, respectively). The hydrogen ions neutralize the surface charge, forming on the surface a functional grouping consisting of hydroxyl and bridge groups $(\mathrm{Ti}-\mathrm{O}(\mathrm{H})-\mathrm{Ti})$ [13].

Secondly, in the surface layer of the titanium hydroxide particles, there are cavities formed by oxygen atoms that are both valence-saturated and unsaturated from the matrix. The size of these atoms is discrete and is determined by the method of packing of the cavity forming atoms (tetrahedron, octahedron, cube, etc.). Various cavities may be adjacent and separated by the oxygen atoms that are common to them.

Thirdly, the cation sorption in the cavity can occur without the prior dissociation of functional groups and is energetically determined by the possibility of replacing the hydration shell of the ion with "solvating" oxygen atoms of cavity, followed by displacement of hydrogen ions, a process similar to the formation of surface titanates [14].

Such a structure of the hydrated titanium dioxide surface can explain the prevailing sorption of lithium and potassium ions by anatase and amorphous titanium dioxide at low $\mathrm{pH}$ values ( $\mathrm{p} K$ around 7 ) by the presence of a structural correspondence between the absorbed ion and the center of sorption - a cavity formed by oxygen atoms. At the same time, taking into account the proximity of the sizes of potassium and barium cations, the reason for the similarity of their sorption behavior becomes clear. The interaction of a cation in the cavity with electrodonor oxygen atoms, which occurs at the same time, leads to an increase in the energy of cation-cavity interaction due to the increase of the covalent component. It is the growth of the fate of the covalent contribution to the energy of interaction, on the one hand, and the difference in the energies of hydration and "solvation" of the cation cavity, on the other hand, that leads to a right-hand displacement of the ion-exchange reaction equilibrium

$$
\mathrm{M}-\mathrm{O}-\mathrm{H}^{+}+\mathrm{Kat}^{+} \rightarrow \mathrm{M}-\mathrm{O}-\mathrm{Kat}^{+}+\mathrm{H}^{+}
$$

and determines a noticeable difference in the acidity of the adsorption centers in the absorption of alkali and alkaline earth metal ions (the first phase of the exchange).

In the second stage, which includes the preliminary dissociation of functional hydroxyl groups that are not part of the cavities, there is no noticeable difference in the acidity of the adsorption centers, depending on the type of cation.

The third stage of the exchange, most pronounced for amorphous titanium hydroxide, is obviously associated with bridge groups, the amount of which in amorphous modification must be much greater, because the formation of titanium hydroxide occurs through the polymerization step of polydynamic complexes, which are connected by the bridge groups.

The analysis of the crystallochemical features of the structure of the investigated modifications of titanium hydroxide shows that in the surface layer of crystallites there are cavities for- 
med by different combinations of octahedra $\left[\mathrm{TiO}_{6}\right]$ - the main structural unit of the lattice, where absorbed cations can be located. Considering the location of oxygen atoms on the facets, we can distinguish three types of cavities. For anatase, these are distorted tetrahedron (oxygen atoms 1-4), octahedral cavity (5-9), and distorted cube (6-13). On the surface of the considered face of rutile, only two types of cavities can be distinguished tetrahedral (1-4) and octahedral (5-9). For amorphous modifications of hydrated titanium dioxide, it is possible to have all types of cavities found on the facets of crystalline modifications. This gives reason to believe that the place of lithium cations localization in the first stage can be tetrahedral cavities, and for potassium cations cubic, the absence of which in rutile explains the difference in the sorption of these cations compared with anatase. The difference in the absorption of $\mathrm{Li}^{+}$by these modifications of hydrated titanium dioxide is due, apparently, to the geometric dimensions of tetrahedral cavities, which are smaller in the anatase because of the difference in the length of Ti-O bonds. Available on the surface of all modifications of titanium dioxide octahedral type cavities when absorbing of alkali and alkaline earth metal ions are not filled due to the difference in size [15] (Fig. 1).

Known from the literature the ability of hydrated titanium dioxide to selectively absorb ions of transition metals, the average ionic radii of which are in the gap between the sizes of cations of lithium and potassium, on the one hand, and the presence on its surface of octahedral cavities with dimensions, intermediate between tetrahedral and cubic, on the other hand, allow assuming that they are the sorption centers of $d$-metal cations [14].

The proposed structure of the sorption centers of hydrated titanium dioxide involves inhibition during simultaneous sorption of ions that are selectively absorbed. The total amount of sorption from binary solutions containing lithium and potassium ions is significantly lower than the corresponding values of single-component solutions. The presence of $\mathrm{Na}^{+}$in solutions with $\mathrm{Li}^{+}$practically does not affect the sorption of the latter, but the reverse effect is very significant: in the pre-

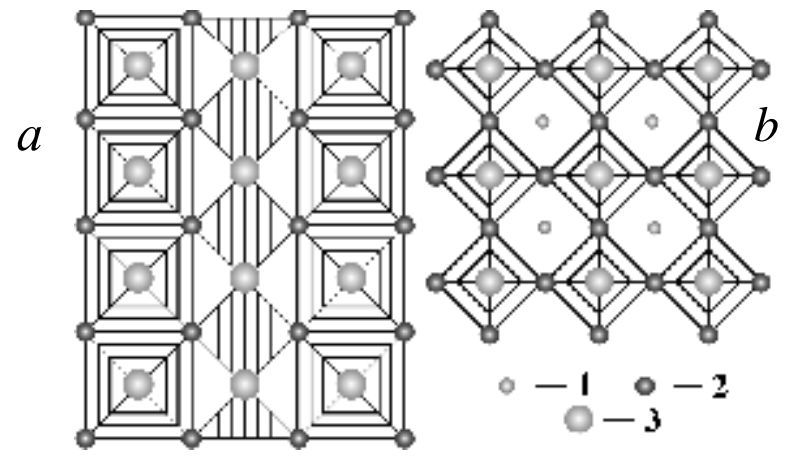

Fig. 1. Schematic representation of crystallographic facets of rutile $(a)$ and anatase $(b)$ with oxygen atoms: $1-$ below, 2-on, and 3-above the picture plane.

sence of $\mathrm{Li}^{+}$or $\mathrm{K}^{+}$sorption of $\mathrm{Na}^{+}$is significantly reduced. The mechanism of such interaction can be explained by mapping the surface in the form of charged cavities, the size of which corresponds to $\mathrm{Li}^{+}$and $\mathrm{K}^{+}$. In this case, for sorption from one-component solutions, a certain surface area is capable of absorbing twice the amount of one ion than when two-component solution is used. However, the surface of titanium dioxide does not contain cavities of the corresponding size of sodium cation, therefore, for sorption from a multicomponent solution containing cations of lithium or potassium, sorption of sodium is practically absent [16].

The main method for obtaining titanium dioxide is the hydrolysis of its various salts. At low $\mathrm{pH}$ values, primary products are salts of variable composition. At higher $\mathrm{pH}$, hydrated forms of titanium dioxide are formed, the content of water molecules in which depends on aging and drying conditions. Freshly deposited titanium dioxide has a high adsorption capacity both for cations and anions. The resulting gel is non-porous with particle size of $30-60 \AA$, aggregated into chains or clusters. The specific surface of the gel is $250-$ $500 \mathrm{~m}^{2} / \mathrm{g}$ depending on the conditions of deposition. During the thermal treatment of gels, it crystallizes to form anhydrous $\mathrm{TiO}_{2}$. Depending on the heating temperature, polymorphic transformations of hydrated titanium dioxide into anatase, rutile or brookite, accompanied by a change in the specific surface and porous structure, are possible. Thus, at temperature below $600{ }^{\circ} \mathrm{C}$, the crys- 
tallization process proceeds with the formation of an anatase with practically the same values of pore volume and specific surface area. At higher temperatures, the transition of anatase to rutile is observed, which is accompanied by a sharp decrease in pore volume and specific surface. Mineral impurities may also affect the temperature of polymorphous transformation. Recently, the sol-gel method is increasingly used to obtain titanium dioxide, which allows obtaining of nanoscale particles of titanium dioxide with given structure and properties. The formation of spherical granules of gel occurs due to alkaline coagulation of dispersed particles of hydrosol. Another way of obtaining hydrogels - through the stage of volume neutralization of excess acidity of the initial salt solution of multi-valent metal with ammonia [17].

Sorption properties. According to [18] titanium dioxide exhibits anion exchange properties in acidic and neutral solutions and cation exchange properties in alkaline solutions. The presence of such amphoteric properties is explained by the hydrolysis of this oxide with the formation of a surface layer of hydroxide and its dissociation in two directions, with the formation of functional groups $\mathrm{H}^{+}$and $\mathrm{OH}^{-}$capable of exchange. Colloidal titanium dioxide is considered to be a sorbent capable of molecular sorption of salts and acids, and notes that the sorption of neutral salts is negligible in comparison with sorption of acids [14]. It was found that from a mixture of two acids - sulfuric and hydrochloric - the sulfuric acid is adsorbed predominantly. At a significant equilibrium concentration of sodium sulfate (sulfuric acid is formed by the interaction of hydrochloric acid containing in ash and sodium sulfate), the dependence of the sorption of sulfate ions on the $\mathrm{pH}$ of the solution is linear.

Titanium dioxide has cation exchange properties and in water the reaction of hydrolyzation occurs as follows:

$$
\mathrm{TiO}_{2}+2 \mathrm{H}_{2} \mathrm{O} \leftrightarrow \mathrm{TiO}_{2}(\mathrm{OH})_{2}{ }^{2-}+2 \mathrm{H}^{+}
$$

where hydrogen ions provide the ability to cation exchange.

The ion exchange properties of amphoteric oxides and hydroxides are usually influenced by two factors. First, the composition and structure of the sorbent. Available impurities can dramatically change the capacity and selectivity of the ion exchanger. The structure of the sorbent also has an effect on the selectivity of the sorption - crystalline ionites have a significantly higher selectivity than amorphous. The second factor is the solution parameters, the most important of which is the concentration of hydrogen ions. Since the most ion exchangers are weak bases and weak acids, this dependence is very noticeable.

The patterns of ion exchange on amphoteric oxides and hydroxides can be explained from the point of view of two possible mechanisms.

In the first mechanism, functional groups, capable of exchanging are groups of $\mathrm{H}^{+}$and $\mathrm{OH}^{-}$on the surface or in the volume of oxide and hydroxide [18]. In this case, the exchange sorption is usually strongly dependent on the $\mathrm{pH}$ of the solution, since the dissociation reaction of the acid or base type with the transition of protons or hydroxyl ions into the outer part of the double electric layer is determined primarily by the $\mathrm{pH}$ of the solution.

The second mechanism of ion exchange relates to materials with impurities capable of sorption. The impurities may be prepresent in the sorbent or formed when material is in contact with solution. In this case, the amphoteric oxide or hydroxide functions as a rigid skeleton with fixed groups capable of exchange. Depending on the nature of the functional groups, these sorbents may be weak or strong ion exchangers. Often such ion exchangers have larger capacity than pure oxides and hydroxides.

Literary data indicate that the following sorption processes are possible on amphoteric oxides and hydroxides:

- ion exchange in the primary layer with potential-determining ions (cations in acidic, anions in alkaline medium);

- ion exchange in the outer layer (anionic in acid, cationic in alkaline medium);

- simultaneous anion and cation exchange in the outer layer (near the isoelectric point);

- chemical sorption in acidic medium with the formation of basic salts and other surface compounds; 
- chemical sorption in an alkaline environment with the formation of aluminates, ferrites, zincates and other compounds;

- molecular sorption at high concentrations of electrolyte and close to neutral $\mathrm{pH}$;

- exchange of cations and anions in molecules sorbed by mechanism of molecular sorption on cations and anions of solution;

- simultaneous sorption of anions with multiply charged cations and cations with multiply charged anions associated with recharging of the surface.

According to the research [19], the adsorption of double charged metal cations on the surface of oxides and hydroxides from solutions of strong electrolytes does not depend on the electrolyte anion (except when the metal forms an amorphous complex with an anion), the dependence of adsorption behavior on ionic strength varies for different electrolytes. For example, in solutions of sodium nitrate ionic strength has almost no effect, in contrast to sodium chloride solutions, in which the sorption of transition metals decreases with increasing ionic strength, although $\mathrm{NaClO}_{4}$ solutions are observed to increase of adsorption capacity with increasing ionic strength.

Also, the influence of intercalation processes on the properties of inorganic materials is considered [20]. Intercalation is reversible topotaxial chemical reactions with the inclusion of impurity molecules in the matrix of solids. Such mechanism allows the synthesis of new compounds with a complex of unique physico-chemical properties. "Guest" molecules are embedded in the interlayer space, which leads to the fact that into the same matrix molecules quite different in size and geometry can intercalate, that is, the molar-sieve effect is absent. Relative ease of inclusion in the interlayer space of hydrated titanium dioxide of various ions allows to create structures with an adjustable composition and the size of interlayer space, which have selective ion exchange properties.

Also, in the literature there are investigations of sorption properties of thermally treated titanium dioxide in comparison with non-treated in the sorption of several cations. It was found that the heating of hydroxides to $400{ }^{\circ} \mathrm{C}$ does not effect the amphoteric properties of the material, but significantly reduces the cation exchange capacity of the sorbent by reducing the content of $\mathrm{OH}^{-}$ groups and reducing the surface area. The sorption capacity of the material correlates with the size of the hydrated cation, the rate of sorption is determined by the diffusion of cation to the $\mathrm{OH}-$ group, not the ion exchange. However, in some samples during the calcination, increasing mesoporosity increases the availability of OH-groups for exchange, so the dependence of the sorption rate on the diffusion of hydrated ion is negligible, as in the case of non-porous gels [21].

Studies [22] demonstrated that ion exchange characteristics are very dependent on obtaining conditions. And in the study of the distribution coefficients of some cations, it was found that hydrated oxides of metals do not have a direct correlation with change in porosity [23], specific surface area, and density of the material obtained as a result of the previous heat treatment. In addition, the distribution coefficients of cobalt ions on crystalline titanium dioxide increase with increasing temperature of calcination [24].

\section{Manganese oxides}

Porous crystals are interesting with their specific properties and variety of structures. Aluminosilicates, including zeolites, clay minerals and mesoporous silicates, can be distinguished as the main classes, but in recent years attention has been paid to porous materials from transition metal oxides. Manganese oxides with tunnel and layered structures can represent a wide range of materials from ultra-microporous to mesoporous. Most manganese oxide structures consist of octahedras $\mathrm{MnO}_{6}$ separated by angles or facets [25].

Macroporous silicon granules and macroporous gel beads from cellulose were used as carriers for selective lithium ion sieves, but their capacity was very limited. Other studies have suggested the use of polyvinyl chloride and polysulfone for granulation or membrane creation, but it is difficult to implement on an industrial scale due to environmental problems with the use of these materials. Non-woven fabric, which is also used as a carrier for ion sieve, does not provide sufficient delay in the particles of the selective material [26]. 
It is suggested to create lithium-selective material based on polyurethane template method. Since the obtained foam was porous and inert, there should not have been a significant reduction in the adsorption capacity/capacity of the introduced material, but this was not confirmed experimentally. The capacity has dropped significantly compared to pure lithium manganate [27].

Since manganese oxides exhibit excellent cation exchange and adsorption properties, they can be used as ion sieves, molecular sieves and catalysts, as well as aluminosilicates. The electrochemical and magnetic properties of manganese oxides allow their use as cathode materials in lithium batteries and modern magnetic materials.

Structure of manganese oxides. Today, many types of tunnel and layered porous manganese oxide are known. The structural variability of oxides is determined by the reversible conversion between $\mathrm{Mn}^{3+}$ and $\mathrm{Mn}^{4+}$ and the formation of defects in crystals.

According to the classification, proposed in [28] tunnel and layered manganese oxides can be divided into groups of pyrolusite-ramsdellite with $(1 \times n)$ tunnel structure, hollandite-romanechite with $(2 \times n)$ tunnel structure and todorokite with $(3 \times n)$ tunnel structure. All structures contain chains of octahedras $\mathrm{MnO}_{6}$, connected by faces, and numbers 1, 2, 3 and $n$ show the number of octahedra along the width of one lattice. Chains, connected through an angle, form a one-dimensional tunnel network. When $n=8$, the network corresponds to a layered structure.

Schematically, the structures of some manganese oxides with one-dimensional tunnel and layered structures are shown in Fig. 2. The structures of the pyrolusite and ramsdellite have one-dimensional tunnel structures respectively. On the other hand, oxides such as birnessite and buserite have layered structures with main ranges of about 0.7 and $1.0 \mathrm{~mm}$, respectively [29].

Metal ions can occupy tunnels of hollandite, romanechite, todorokite, $\mathrm{Rb}_{0.27} \mathrm{MnO}_{2}$, and also the interlayer space of birnessite. Mangan in oxides is predominantly quadrivalent, but part of it is trivalent to compensate the charge of impurity ions.

Also, in manganese oxides, nonperiodic growth

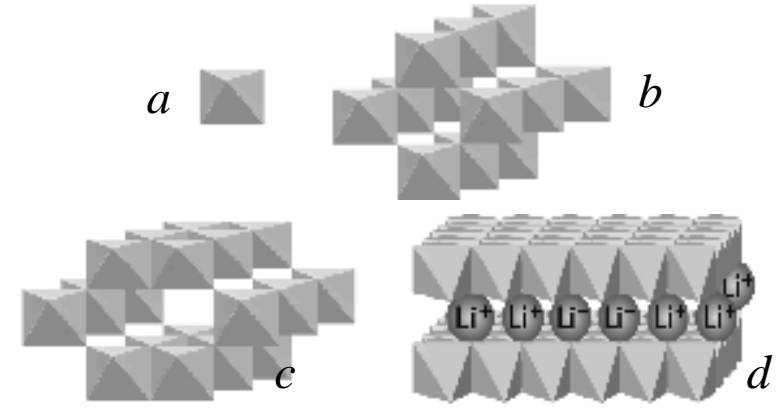

Fig. 2. Schematic representation of one-dimensional tunnel and layered manganese oxides: $a-\mathrm{MnO}_{6}$ octahedron; $b-(1 \times 1)$ tunnel pyrolusite; $c-(1 \times 2)$ tunnel ramsdellite; $d-(1 \times 8)$ layer lithium-manganese spinel.

of two or more tunnel phases is observed. In addition to one-dimensional $(m \times n)$ tunnels, other types of layered and tunnel structures are also known. For example, the spinel has a three-dimensional (1 x 3) network of tunnels with a combination of $8 \mathrm{a}$ tetrahedral units and 16s empty octahedral units of a cubic dense pack of oxygen lattice. It is possible to form a series of spinels of the general formula $\mathrm{Li}_{n} \mathrm{Mn}_{2-x} \mathrm{O}_{4}(1 \leq n \leq 1.33,0 \leq x \leq$ $0.33, n \leq 1+x)$. Typical representatives of this series are $(\mathrm{Li})\left[\mathrm{Mn}^{\mathrm{III}} \mathrm{Mn}^{\mathrm{IV}}\right] \mathrm{O}_{4}$ and $(\mathrm{Li})\left[\mathrm{Li}_{0.33} \mathrm{Mn}^{\mathrm{IV}}{ }_{1.67}\right] \mathrm{O}_{4}$, where ( $)$ and [] are 8a tetrahedral and 16d octahedral units, respectively. In the spinel (Li) $\left[\mathrm{Mn}^{\text {III }}\right.$ $\left.\mathrm{Mn}^{\mathrm{IV}}\right] \mathrm{O}_{4}$, lithium cation occupies the tetrahedral location of $8 \mathrm{a}$, and the trivalent and quadrivalent manganese - $16 \mathrm{~d}$ octahedral. In $(\mathrm{Li})\left[\mathrm{Li}_{0.33^{-}}\right.$ $\mathrm{Mn}^{\mathrm{IV}}{ }_{1.67} \mathrm{O}_{4}$, lithium is placed at $8 \mathrm{a}$ tetrahedral and free $16 \mathrm{~d}$ octahedral, and the whole manganese is quadrivalent [30].

Synthesis of ion exchangers based on manganese oxides. Synthesis of ion and molecular sieves based on manganese oxide can be presented in two stages: (1) tunnel or layered oxide is prepared using template ions or molecules to form tunnel sizes and between spherical cavities; (2) template ions and molecules are topotactically removed from the material with the formation of a sieve. Such manganese oxides can be formed using a variety of processes that can be conventionally divided into dry processes (solid phase reactions and interaction of salt melts), wet processes (oxidative-reductive deposition, hydrothermal chemical processes) and mixed processes (sol-gel). Stable phases 
with small sized gaps such as spinel, hollandite, romanechite, and birnessite can be synthesized by any of these processes. The ion-sieve, electrochemical and catalytic properties of manganese oxides often depend on the synthesis conditions.

In solid-phase reactions, the size of obtained defects in structure depends on the size and amount of metal ions used as templates. The source of manganese for such syntheses may be $\mathrm{MnCO}_{3}$, $\mathrm{MnO}_{2}, \mathrm{Mn}_{2} \mathrm{O}_{3}, \mathrm{MnOOH}, \mathrm{Mn}\left(\mathrm{CH}_{3} \mathrm{COO}\right)_{2}$, etc., and the source of metal cations is $\mathrm{M}_{2} \mathrm{CO}_{3}, \mathrm{MOH}$, $\mathrm{MNO}_{3}, \mathrm{MCH}_{3} \mathrm{COO}$, and others.

Manganese oxide with spinel structure is prepared using lithium cation. Since manganese oxides play a significant role as cathode materials in batteries, a large number of studies are devoted to finding an effective method for their synthesis. The series of $\operatorname{LinMn}_{2-x} \mathrm{O}_{4}(1 \leq n \leq 1.33,0 \leq x \leq$ $0.33, n \leq 1+x)$ oxides can be obtained in the temperature range of $350-900^{\circ} \mathrm{C}$. The degree of oxidation of manganese and the composition of the oxide formed depend on such conditions as the temperature, the source materials and the atmosphere in which the synthesis takes place. Spinel (Li)[Mn ${ }^{\text {III }}$ $\mathrm{Mn}^{\mathrm{IV}} \mathrm{O}_{4}$ is formed at high temperature (above $700{ }^{\circ} \mathrm{C}$ ), and spinel $(\mathrm{Li})\left[\mathrm{Li}_{0.33} \mathrm{Mn}^{1 \mathrm{~N}_{1.67}}\right] \mathrm{O}_{4}$ - at low (below $500{ }^{\circ} \mathrm{C}$ ) [31].

Ooi and colleagues [32] investigated the effect of the template alkali metal cation on the solid-phase reaction process. The authors have cooled $\gamma-\mathrm{MnO}_{2}$ saturated with metal ions $\left(\mathrm{Li}^{+}\right.$, $\mathrm{Na}^{+}, \mathrm{K}^{+}$) at $600^{\circ} \mathrm{C}$ for two hours. With lithium the spinel was obtained, and with cations of sodium and potassium - hollandite.

Also, some techniques based on the sol-gel method have been developed to produce spinel [33] and his colleagues received $\mathrm{Li}_{x} \mathrm{Mn}_{2} \mathrm{O}_{4}$ spinel by precipitation of $\mathrm{Mn}\left(\mathrm{CH}_{3} \mathrm{COO}\right)_{2}$ solution with lithium hydroxide and subsequent precipitate calcination at $300{ }^{\circ} \mathrm{C}$. Scientist [34] received a highly crystalline spinel $\mathrm{Li}_{4} \mathrm{Mn}_{5} \mathrm{O}_{12}$ by heating eutectic mixture of LiOAc and $\mathrm{Mn}\left(\mathrm{NO}_{3}\right)_{2}$ to $700{ }^{\circ} \mathrm{C}$ under an atmosphere of oxygen. Sol-gel process was developed for spinel and birnessite [35]. $\mathrm{AMnO}_{4}$ [A $\left.=\mathrm{Li}, \mathrm{Na}, \mathrm{K}, \mathrm{NH}_{4}, \mathrm{~N}\left(\mathrm{CH}_{3}\right)_{4}\right]$ was reduced with formic acid at room temperature until amorphous xerogel was formed. The spinel phase and $\mathrm{LiMnO}_{2}$ were formed during the calcination of the $\mathrm{LiMnO}_{4}$ $-\mathrm{C}_{4} \mathrm{H}_{4} \mathrm{O}_{4}$ gel at 600 and $1000{ }^{\circ} \mathrm{C}$, respectively.

In addition to the above, the methods of synthesis of spinel and birnessite by hydrothermal treatment of $\gamma-\mathrm{MnO}_{2}$ in solutions of lithium and potassium or sodium hydroxides are also developed.

Sorption properties of manganese oxides. Ooi divided the adsorption centers of manganese oxides into specific (in volume of the crystal) and nonspecific (on the crystal surface). Specific centers in turn are divided into ion exchange and oxidative-reductive [36].

The ion-sieve properties of manganese oxide are investigated by potentiometric titration and by measurements of the scattering factor. The spinel type ion sieves show a significantly higher sorption capacity for lithium relative to sodium and potassium, due to the size of lithium ion that can pass through the tunnel, smaller than the sodium and potassium ions. Sodium and potassium are adsorbed on the surface of crystals (non-specific adsorption), and lithium adsorbs at specific centers after dehydratation. Although bivalent ions such as $\mathrm{Mg}^{2+}, \mathrm{Ni}^{2+}, \mathrm{Co}^{2+}$ are also characterized by small radii, they do not pass through the tunnel, since their dehydratation energy is too high [36].

Hollandite type ion sieves show high values of capacity for potassium ion at low $\mathrm{pH}$. With increasing $\mathrm{pH}$, the adsorption capacity increases with decreasing ion radius, as the steric interactions between metal ions in the tunnel begin to predominate.

Birnessite ion sieves have different adsorption properties for small and large ions, for example, they are tribasic or dibasic acids relative to $\mathrm{Li}^{+}$and monobasic relative to $\mathrm{Na}^{+}, \mathrm{K}^{+}, \mathrm{Cs}^{+}$.

Similar characteristics are also given to ion sieves of todorokite type, such as dicarboxylic acids for lithium, sodium, and potassium ions, and monobasic for cesium ions. This is since large ions can be adsorbed only in the center of the tunnel, while the small ones are located closer to the walls. The pore radius of the pyrolusite and ramsdellite is too small for metal ions, so the latter are adsorbed only on the surface.

The selectivity of the ion sieves of manganese oxide directly depends on their structure. For 
example, for a spinel, the selectivity increases in the series $\mathrm{Na}^{+}<\mathrm{K}^{+}<\mathrm{Rb}^{+}<\mathrm{Cr}^{+}<<\mathrm{Li}^{+}$, for hollandite $\mathrm{Li}^{+}<\mathrm{Cs}^{+}<\mathrm{Na}^{+}<<\mathrm{Rb}^{+}<\mathrm{K}^{+}$, for birnessite $\mathrm{Li}^{+}<$ $\mathrm{Na}^{+}<\mathrm{Cs}^{+}, \mathrm{K}^{+}<\mathrm{Rb}^{+}$, and for todorokite $\mathrm{Li}^{+}<\mathrm{Na}^{+}<$ $\mathrm{K}^{+}<\mathrm{Rb}^{+}<\mathrm{Cs}^{+}$. Such dependencies are explained by the structure of the material: $(1 \times 3)$ the spinel tunnels fit in size for the lithium ion, $(2 \times 3)$ tunnels for potassium and rubidium ions, interlayer spaces in birnessite correspond to the size of rubidium ion. The dependence of selectivity for todorokite coincides with the growth of the ionic radii of metals, since all the ions are contained in $(3 \times 3)$ tunnels.

Volkhin and others found that spinel type oxide without metallic ions in tunnels can be obtained by extraction of lithium with acid from a spinel type lithium manganate. Spinel exhibits adsorption properties to lithium ion [37]. The oxidation-reduction mechanism of the reaction was proposed:

$$
\begin{gathered}
4(\mathrm{Li})\left[\mathrm{Mn}^{\mathrm{III}} \mathrm{Mn}^{\mathrm{IV}}\right] \mathrm{O}_{4}+8 \mathrm{H} \rightarrow 3()\left[\mathrm{Mn}^{\mathrm{IV}}{ }_{2}\right] \mathrm{O}_{4}+ \\
+4 \mathrm{Li}^{+}+2 \mathrm{Mn}^{2+}+4 \mathrm{H}_{2} \mathrm{O} .
\end{gathered}
$$

The driving force for delitiation is the disproportionation reaction of $\mathrm{Mn}^{\mathrm{III}}$ to $\mathrm{Mn}^{\mathrm{IV}}$ and $\mathrm{Mn}^{\mathrm{II}}$ in acidic medium. The oxidative-reducive release of one lithium cation is provided by the disproportionation of one $\mathrm{Mn}^{\mathrm{III}}$ atom by the reaction

$$
\mathrm{Mn}^{\mathrm{III}} \rightarrow 1 / 2 \mathrm{Mn}^{\mathrm{IV}}+1 / 2 \mathrm{Mn}^{\mathrm{II}} \text {, }
$$

in the non-lithium spinel the whole manganese is quadrivalent.

When lithium is adsorbed, there is an inverse reaction of the transition of a part of tetravalent manganese to trivalent with the release of oxygen.

$$
\begin{gathered}
(\mathrm{)})\left[\mathrm{Mn}_{2}^{\mathrm{IV}}{ }_{2} \mathrm{O}_{4}+\mathrm{LiOH} \rightarrow(\mathrm{Li})\left[\mathrm{Mn}^{\mathrm{III}} \mathrm{Mn}^{\mathrm{IV}}\right] \mathrm{O}_{4}+\right. \\
+0.5 \mathrm{H}_{2} \mathrm{O}+0,25 \mathrm{O}_{2} .
\end{gathered}
$$

On the other hand, there is also ion exchange mechanism for the adsorption/release of lithium ion. Studies have shown that the choice of an oxidative-reductive or ion-exchange mechanism depends on the degree of oxidation of manganese and the distribution of metal ions in the spinel. The reaction of ion exchange is as follows:

$$
\text { (Li) }\left[\mathrm{Li}_{0.33} \mathrm{Mn}^{\mathrm{IV}}{ }_{1.67}\right] \mathrm{O}_{4}+1.33 \mathrm{H}^{+} \leftrightarrow
$$

$$
\leftrightarrow(\mathrm{H})\left[\mathrm{H}_{0.33} \mathrm{Mn}^{\mathrm{IV}}{ }_{1.67}\right] \mathrm{O}_{4}+1.33 \mathrm{Li}^{+} .
$$

In this spinel, the whole manganese is quadrivalent $\left(\lambda-\mathrm{MnO}_{2}\right)$, so the dispersion reaction does not occur in the acidic medium. In the spinel structure, one $\mathrm{Mn}^{\mathrm{III}}$ ion corresponds to one oxidative-reductive center, and one Mn defect in the $16 \mathrm{~d}$ octahedral structure corresponds to four ionexchange centers. In most real spinels there are both oxidative-reductive and ion-exchange centers, number of each depends on the conditions of the spinel [38].

Another variant of this type of manganese oxides can be obtained by introducing bivalent and trivalent metal cations into the lithium manganese spinel. The oxidative-reducive spinel contains metal ions that can be oxidized to higher valences when lithium cations leave spinel cavities.

The spinel type manganese oxides exhibit selectivity to lithium against sodium and potassium, as lithium cation due to a small radius can penetrate the spinel structure tunnel without potassium and sodium cations. The latter are nonselectively adsorbed on the surface of the crystal, while $\mathrm{Li}^{+}$adsorbed on specific centers after dehydratation.

CONCLUSIONS. It is possible to satisfy the demand due to the effective removal of lithium from cheap primary or secondary resources, in particular by obtaining it from brines or sea water, where the most promising is the use of ion-exchange selective materials.

Hydrated titanium dioxide contains in its structure cavities of various shapes and sizes, which may allow sorption of certain ions, without dissociation of functional groups. And with the help of directed thermal synthesis it is possible to create a certain size of cavities in the structure of hydrated titanium dioxide.

Lithium magnesium spinels are the most suitable for sorption of lithium ions, due to high selectivity for lithium and a good sorption capacity, but these compounds are characterized by unsatisfactory physical properties due to the fragility of the material. The combination of the material formed on the basis of hydrated titanium dioxide with known lithium manganese 
spinels allows to obtain a strong ion-exchange material for the selective extraction of lithium ions.
К л ю ч о в і с л о в а: діоксид титану, оксид мангану, літій, іонний обмін.
МАТЕРІАЛИ НА ОСНОВІ ОКСИДІВ ТИТАНУ I МАНГАНУ ДЛЯ СЕЛЕКТИВНОГО ВИЛУЧЕННЯ ЛІТІЮ 3 ВОДНИХ ДЖЕРЕЛ

М.О. Чабан*, Ю.С. Дзязько, О.В. Бистрик

Інститут загальної та неорганічної хімії ім. B.І.Вернадського НАН України, просп. Академіка Палладіна, 32/34, Київ, 03142, Україна *e-mail: mary.chaban@gmail.com

Через постійно зростаюче виробництво електронних портативних пристроїв, в тому числі гаджетів, для одержання літій-іонних акумуляторів необхідно шукати способи вилучення літію. Літій $є$ електрохімічно активним, має найвище значення окисно-відновного потенціалу і найвищу питому теплоємність серед твердих матеріалів, що робить його ключовим елементом у сучасній революції електричних транспортних засобів. Земна кора містить близько $0.007 \%$ літію, не у чистому вигляді, а його незначні концентрації виявляються практично у всіх вулканічних породах, а також у водах мінеральних джерел, морській воді та океанах. Існує більше 20 мінералів, що містять літій, але лише деякі 3 них мають вміст, достатній, щоб викликати комерційний інтерес. Перспективним напрямком є переробка розсолів, що утворюються після опріснення морської води і шахтних вод. Цей напрямок вважається екологічно чистим і рентабельним. Оскільки концентрація літію в таких ресурсах є низькою, сорбційні методи видаються більш доречними, порівняно 3 іншими. У даній статті описані матеріали, що широко вивчаються 3 метою отримання літій-селективних адсорбентів. Більшість амфотерних оксидів i гідроксидів $\epsilon$ амфотерними йонообмінниками, що здатні як до катіонного, так і до аніонного обміну. Ці матеріали представляють науковий інтерес у зв'язку з вивченням поведінки радіоактивних ізотопів, дезактивації стічних вод та концентрування мікрокількостей елементів. Синтез таких іонообмінників, як амфотерні оксиди і гідроксиди, є досить простим, i їхня вартість на одиницю ємності в більшості випадків набагато нижче, ніж органічних смол. Комбінація матеріалів на основі гідратованого діоксиду титану 3 відомими літієвими марганцевими шпінелями дозволяє отримати іонообмінний матеріал для селективного вилучення іонів літію.

\section{МАТЕРИАЛЫ НА ОСНОВЕ ОКСИДОВ ТИТАНА И МАРГАНЦА ДЛЯ СЕЛЕКТИВНОГО ИЗВЛЕЧЕНИЯ ЛИТИЯ ИЗ ВОДНЫХ ИСТОЧНИКОВ}

М.А.Чабан*, Ю.С.Дзязько, О.В.Быстрик

Институт общей и неорганической химии им. В.И.Вернадского НАН Украины, просп. Академика Палладина, 32/34, Киев, 03142, Украина *e-mail: mary.chaban@gmail.com

Из-за постоянно растущего производства электронных портативных устройств, в том числе гаджетов, для получения литий-ионных аккумуляторов необходимо искать способы извлечения лития. Земная кора содержит около 0.007 \% лития, не в чистом виде, а его незначительные концентрации оказываются практически во всех вулканических породах, а также в водах минеральных источников, морской воде и океанах. Существует более 20 минералов, содержащих литий, но лишь немногие из них имеют содержание, достаточное, чтобы вызвать коммерческий интерес. Перспективным направлением является переработка рассолов, образующихся после опреснения морской воды и шахтных вод. Это направление считается экологически чистым и рентабельным. Поскольку концентрация лития в таких ресурсах низкая, сорбционные методы кажутся более уместными, по сравнению с другими. В данной статье описаны материалы, которые широко изучаются с целью получения литий-селективных адсорбентов. Большинство амфотерных оксидов и гидроксидов являются амфотерными ионообменниками, способными как к катионному, так и к анионному обмену. Такие материалы представляют научный интерес в связи с изучением поведения радиоактивных изотопов, дезактивации сточных вод и концентрирования микроколичеств элементов.

К л ю ч е в ы е с л о в а: диоксид титана, оксид марганца, литий, ионный обмен.

\section{REFERENCES}

1. Ayres R.U. On the practical limits to substitution. Ecol. Econ. 2007. 61 (1): 115.

2. Giurco D., Prior T., Mudd G., Mason L. and Behrisch J. Peak minerals in Australia: a review of changing impacts and benefits. Prepared for CSIRO Minerals Down Under Flagship, by the 
Institute for Sustainable Futures (University of Technology, Sydney) and Department of Civil Engineering (Monash University), March 2010.

3. Ebensperger A., Maxwell P., Moscoso C. The lithium industry: its recent evolution and future prospects. Resour. Policy. 2005. 30 (3): 218.

4. Jaskula B.W. Lithium. Mineral Commodity Summaries. (Reston, 2011).

5. Basudev S. Recovery and recycling of lithium: A review. Sep. and Purif. Techn. 2017. 172: 388.

6. Roskill Reports on Metals and Minerals. 11th Revised edition. Roskill Information Services Ltd. 2009.

7. Mahi P., Smeets A.A.J., Fray D.J., Charles J.A. Lithium - Metal of the Future. 1986. Journal of the Minerals. 38: 20.

8. Naumov A.V., Naumova M.A. Modern State of the World Lithium Market. Russian Journal of Non-Ferrous Metals. 2010. 51 (4): 324.

9. Chegwidden J., Baylis R. Lithium supply - adequate to meet demand from automotive batteries? Intern. Minor. Metals Conf., Istanbul, 2009.

10. Pelly I. Recovery of lithium from Dead Sea brines. Journal of Applied Chemistry and Biotechnology. 1978. 28: 469.

11. Zhabrova G.M., Egorov E.V. Sorption and ion exchange on amphoteric oxides and hydroxides. Russian Chemical Reviews. 1961. 30 (6): 338.

12. Tretyakov Y.D., Putlyaev V.I. Introduction to the chemistry of solid-state materials. (Moscow, 2006). [in Russian].

13. Bagheri S., Hir Z., Yousefi A., Hamid S. Progress on mesoporous titanium dioxide: Synthesis, modification and applications. Microporous and Mesoporous Materials. 2015. 218: 206.

14. Tsydenov D., Shutilov A., Zenkovets G., Vorontsov A. Hydrous $\mathrm{TiO}_{2}$ materials and their application for sorption of inorganic ions. Chemical Engineering Journal. 2014. 251: 131.

15. Myint Y., Moe T., Linn W., Chang A., Win P. The effect of heat treatment on phase transformation and morphology of nanocrystalline titanium dioxide. International Journal of Scientific \& Technology Research Volume. 2017. 6(6): 293.

16. Chitrakar R., Makita Y., Ooi K., Sonoda A. Lithium recovery from salt lake brine by $\mathrm{H}_{2} \mathrm{TiO}_{3}$. Dalton Trans. 2014. 43: 8933.

17. Cargnello M., Gordon T., Murray C. Solutionphase synthesis of titanium dioxide nanoparticles and nanocrystals. Chem. Rev. 2014. 114 (19): 9319.

18. Amphlett C. B. Inorganic ion exchangers. (Elsevier Pub. Co,1964).

19. Criscenti L., Sverjensky D. The role of electrolyte anions in divalent metal adsorption on oxide and hydroxide surfaces in salt solutions. Am. J. Sci. 1999. 299: 828.

20. Fefelova A. Synthesis and sorption properties of hydrated titanium dioxide intercalated with alkali metal ions. Thesis at conference. Student Scientific Forum. 2014.

21. Ramadan A.R., Yacoub N., Bahgat S., Ragai J. Effect of preparative conditions on the surface characteristics of mixed zirconium and titanium oxides. Adsorption. 2007. 13: 291.

22. Komatsu Y., Fujiki Y., Sasaki T. Adsorption of Uranium from Nitric Acid Solutions Using Crystalline Hydrous Titanium Dioxide Fibers. Bull. Chem. Soc. Jpn. 1986. 59: 49.

23. Yamazaki H., Kaneda M., Inoue Y. Effect of heat treatment of hydrous metal oxides on their cation-exchange selectivity. Bull. Chem. Soc. Jpn. 1990. 63 (11): 3216.

24. Yacoub N., Ramadan A., Ragai J. Ion-exchange and Adsorption Properties of Titania Gels Prepared from Titanous Chloride and Hydrogen Peroxide. Adsorption Science \& Technology. 2005. 23 (3): 215.

25. Feng Q., Kanoh H., Ooi K. Manganese oxide porous crystals. J. Mater. Chem. 1999. 9: 319.

26. Shi X., Zhou D., Zhang Z., Yu L. Synthesis and properties of $\mathrm{Li}_{1.6} \mathrm{Mn}_{1.6} \mathrm{O}_{4}$ and its adsorption application. Hydrometallurgy. 2011. 110: 99.

27. Ma L., Chen B., Chen Y., Shi X. Preparation, characterization and adsorptive properties of foamtype lithium adsorbent. Microporous and mesoporous materials. 2011. 142: 147.

28. Tumer S., Buseck P. Todorokites: a new family of naturally occurring manganese oxides. Science. 1981. 212: 1024.

29. Tamada O., Yamamoto N. The crystal structure of a new manganese dioxide $\left(\mathrm{Rb}_{0.27} \mathrm{MnO}_{2}\right)$ with a giant tunnel. Mineralogical Journal. 1986. 13: 130.

30. Thackeray M., Kock A., Rossouw M., Liles D., Bittihn R., Hoge D. Spinel Electrodes from the Li-Mn-O System for Rechargeable Lithium Battery Applications. J. Electrochem. Soc. 1992. 139: 363.

31. Koksbang R., Barker J., Shi H., Saidi M. Cathode Materials for Lithium Rocking Chair Batteries. Solid State Ionics. 1996. 84: 1.

32. Ooi K., Miyaiand Y., Katoh S. Ion-Exchange Properties of lon-Sieve-Type Manganese Oxides Prepared by Using Different Kinds of Introducing Ions. Sep.Sci.Technol. 1987. 22: 1779.

33. Barboux P., Tarascon J., Shokoohi F. The use of acetates as precursors for the low-temperature synthesis of $\mathrm{LiMn}_{2} \mathrm{O}_{4}$ and $\mathrm{LiCoO}_{2}$ intercalation 
compounds. J. Solid State Chem. 1991. 94: 185.

34. Takada T., Hayakawa H., Kumagai T., Akiba E. Thermal stability and structural changes of $\mathrm{Li}_{4} \mathrm{Mn}_{5} \mathrm{O}_{12}$ under oxygen and nitrogen atmosphere. J. Solid State Chem. 1996. 121: 79.

35. Bach S., Pereira-Ramos J., Baffier N., Messina R. Birnessite manganese dioxide synthesized via a sol-gel process: a new rechargeable cathodic material for lithium batteries. Electrochim. Acta. 1991. 36: 1595.

36. Ooi K., Sonoda A., Makita Y. Recovery of lithium from salt-brine eluates by direct crystallization as lithium sulfate. Hydrometallurgy. 2017. 174: 123.

37. Volklin V., Leonteva G., Onorin S. Synthesis, structure and properties of ion sieve cation exchanger ISM-1. Neorg. Mater. 1973. 9: 1041. [in Russian].

38. Leonteva G., Volklin V. Inorganic cation exchangers with sieve effect and its implementation for separation of alkali metals. Zh. Prikl. Khim. 1971. 44: 2615.

Received 05.04.2019 